\title{
13 \\ The road to Wind Nation
}

As Paliau's career in electoral politics came to a close, the Paliau Movement gave rise to the Study Group. This quickly became the Manus Kastam Kansol, usually shortened to Makasol, and Makasol became Wind Nation, the name under which the Movement persists today. From the mid-1950s to the early 1980s, Schwartz was the only anthropological observer, but beginning in the mid-1980s other researchers began to gather data on the Paliau phenomenon. We cannot do justice to all of their work, but we will draw on it when it casts light on the issues that concern us most. Chief among these are the dramatic shift in the Movement's attention to almost wholly millenarian concerns; the role in the Movement from the late 1970s onwards of a number of educated young men with considerable experience in modern institutions, who became Paliau's acolytes; and how Movement leaders managed relationships with the rank and file as the Movement became Wind Nation. We begin, however, by visiting Paliau at the nadir of his career, but poised to enter public life again on new terms.

\section{After the Fall: Paliau in 1973}

For several years after his long stay in the Territory in the 1960s, Schwartz followed Paliau's career from a distance. He next returned to Manus from June through September 1973 to pursue research on matters unrelated to the Paliau Movement. He also, of course, wanted to see what Paliau was doing. Schwartz knew Paliau was living on Baluan, but his research 
agenda required that he and his three assistants (Michael French Smith, Edwin Hutchins, and Geoffrey White) spend several weeks in Pere village and in Lorengau before reaching Baluan in early September.

Schwartz had heard that Paliau was not well. One of Paliau's strongest and most reliable supporters, Lungat of Ndriol, visited Schwartz in Lorengau in August. Lungat told Schwartz that Paliau's political failures had left him despondent and sickly and he asked Schwartz to do his best to help him: 'You can visit him, and maybe seeing and talking with you will help him think good thoughts again'.

Schwartz and his party travelled from Lorengau to Baluan in early September on a motorised outrigger canoe packed tight with passengers and stacked high with goods from town, including several drums of fuel for Baluan boats and generators. They arrived late one afternoon, thoroughly cold and wet after travelling through a heavy storm at sea. Two of Paliau's associates led them to their quarters, a house originally built for resident Australian colonial officers and their families. The amenities those residents had enjoyed-including a shower and a flush toilet fed by a rainwater collection tank on the corrugated metal roofno longer functioned. But the house was dry, spacious, and almost mosquito free.

The next morning, Schwartz found Paliau and his wife, Teresia, living in an ordinary village house that bore no marks of distinction. Wearing a laplap rather than trousers and white shirt, Paliau looked grey and thin. He apologised to Schwartz for his appearance and explained that for many weeks he had been staying in the house, feeling weak. His debility, he said, had started after he was ousted from the Area Authority, but other events also depressed his spirits. He mentioned the land dispute in Bunai and the controversy over management of the council boat. But he was most disturbed because, he said, people weren't following the New Way anymore. They weren't working together or meeting together to discuss village matters and many were putting big money into affinal exchanges. Some were also leaving the Baluan Native Christian Church to go back to the Catholics or to join an evangelical Protestant church: 'I created all this 30 years ago, but now they are abandoning it', Paliau told Schwartz. 
Over the following weeks, Schwartz visited Paliau almost every day. Responding to Schwartz's interest, Paliau gradually stopped bemoaning his present circumstances and began to sound like a man looking ahead. For decades Schwartz had managed to remain a deeply interested observer of Paliau's career without either endorsing or opposing his endeavours. But the hours he spent with the ailing and discouraged man that September and Paliau's obvious appreciation affected him deeply. Paliau was in his mid-60s, an advanced age for a man in rural Papua New Guinea (PNG), and Schwartz couldn't be sure he would ever see him again. He visited Paliau late into the night the day before he and his party left Baluan. Responding to Paliau's effusive thanks for his visit, Schwartz found himself giving Paliau a pep talk. The following exchange is translated from the Tok Pisin in which they conversed:

Paliau: It was just worry that caused this bad illness of mine. But now my mind is clearer and I'm feeling my strength come back. Ted, you can see that I'm better now. You're the reason for this, Ted.

Schwartz: Somewhere you learned how to be a leader. People hear you and people follow you. A lot of other people, they may have good ideas, but they don't have what it takes to lead a village or to bring people together. A leader is a special thing. It isn't something you can learn in school; it's something about the kind of person you are.

Paliau: Ted, what you say is true.

So, Schwartz encouraged Paliau to get moving again. But he couldn't anticipate the direction Paliau would take. He got a clue, however, on a day of special events Paliau arranged just before the Schwartz party left. It was immediately apparent that Paliau still wielded at least local influence because it looked like most of the combined village of LipanMok had turned out. By midday, young people were playing soccer and volleyball on a large open field adjacent to Paliau's house, while men assembled a long banquet table and women and girls piled it high with food. Later, Schwartz and his assistants were ushered to the table, where a number of village leaders (all men) joined them. After the meal, a party of school children in contemporary versions of traditional dress sang songs in English, Tok Pisin, and the Baluan language, and a few senior men made short speeches. When it was time to leave the table, someone told the American guests to stay close by because there was more to come. 


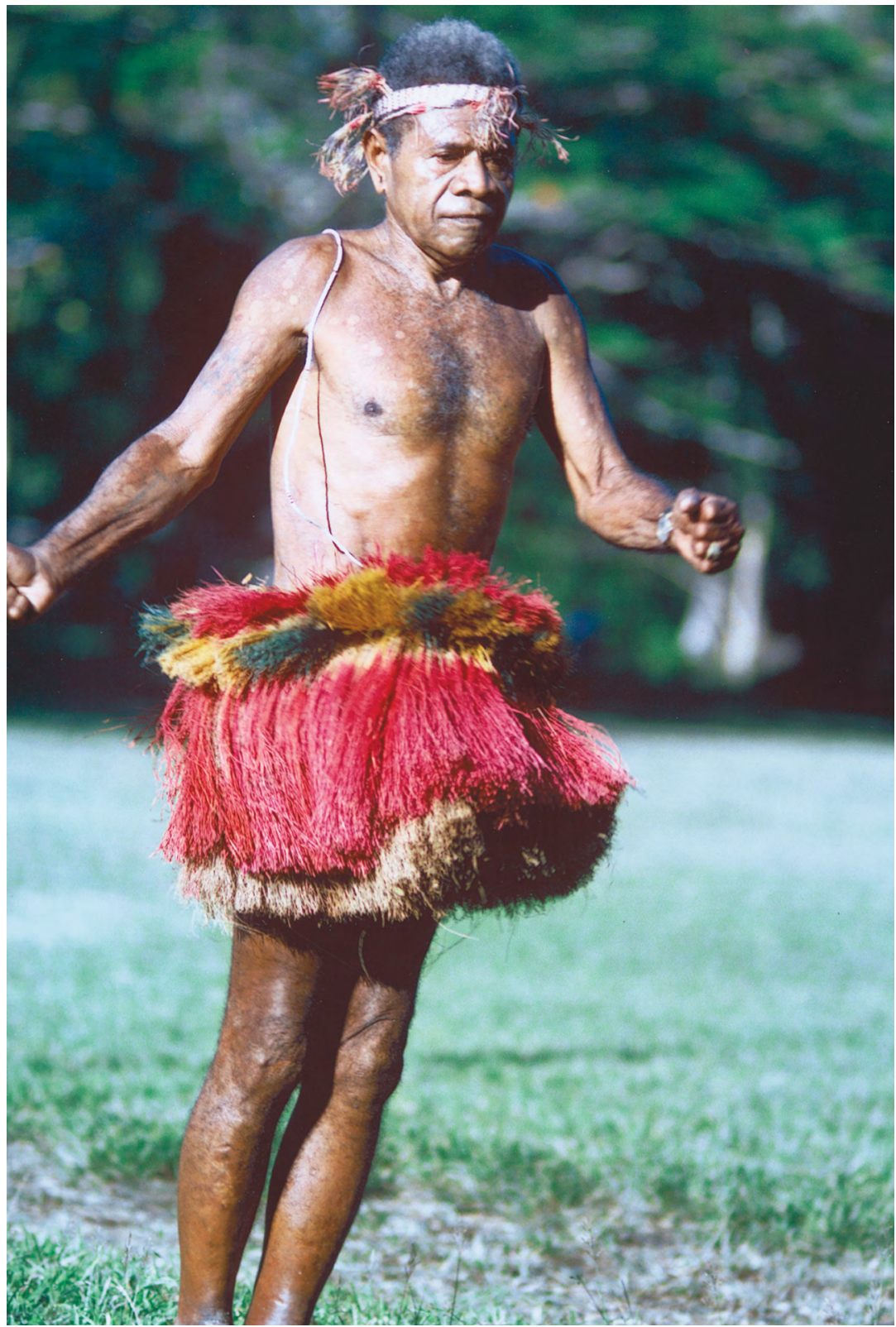

Figure 13.1: In 1973, Paliau surprised Schwartz by dancing in full traditional regalia at an event in Lipan-Mok village, Baluan.

On this visit to Baluan, Schwartz heard from Paliau early inklings of Wind Nation ideology, including ideas that glorified an idealised past that contrasted sharply with the Movement's earlier harsh criticism of many precolonial practices.

Source: Geoffrey White. 
What came was a surprise. Paliau and Teresia came out of their house in colourful indigenous regalia: multilayered and multicoloured fibre skirts, strings of shell beads draped across their chests, and decorated headbands. They walked, dignified and erect, to the centre of the field. Garamut drummers began pounding out a staccato rhythm, punctuated by sudden stops and abrupt starts. The couple positioned themselves and began to dance, stopping and starting their sequences of stiff but athletic movements in perfect synchrony with the drummers. During Paliau's seclusion, Teresia had continued to garden, gather firewood, cook, and care for the house, so it was not surprising to see that she was strong and fit-if also a bit worn from the excess of daily physical work that falls to women in rural PNG. Paliau was thin and wrinkled, but he danced with impressive vigour, belying Schwartz's earlier impression of someone physically weak and emotionally low.

We may have witnessed that day the inaugural event of Paliau's comeback. Paliau was showing Lipan-Mok that people from distant parts of the world still regarded him as important and that he had the energy to lead again. Recall, too, that he regarded his failure in a traditional ceremonial performance in his youth as a formative incident. On that day in 1973, however, he performed skilfully and proudly.

\section{Seeking a new direction}

Schwartz didn't see Paliau again until 1975. By then, Paliau had moved from Baluan to Lorengau. He looked healthy, but in conversation he focused on rehashing the details of his electoral career. Both in Lorengau and in Pere, Schwartz also spoke at length with several men who had been among Paliau's closest allies but had abandoned him (some of whom we met in the previous chapter), and they too harped on the past. Although Schwartz noticed a few younger men among the small group attending Paliau in Lorengau, it would have been easy to assume that Paliau, almost 70 years old now, was slowing to a halt.

But Schwartz had known Paliau too long to jump to that conclusion. In December 1978, Schwartz was back in Manus again, where Paliau was still settled in Lorengau, but eager this time to talk about the future. The country was still under the leadership of its first prime minister, Michael Somare, with whom Paliau had served in the pre-independence House of Assembly. Schwartz asked Paliau his opinion of the current government 
and Paliau said he approved of it and its efforts to help people find ways to earn money. That's what people needed now, he said. But Paliau spoke more passionately about his own ideas for the government of Manus and what he now advocated sounded like theocracy with a dash of cultural revival. He would soon begin openly promoting such an agenda but he was still reluctant to speak of it to Schwartz with full candour.

Paliau told Schwartz that Manus should be governed by a Lapan Assembly, although he didn't expand on the nature of such a body. (Recall that lapan is the Titan word for a person of high rank.) Further, Manus should aspire to 'Government of the Holy Spirit' so that 'later, the kingdom will come'. Schwartz, hearing this from Paliau for the first time, asked if it was a new dimension of the teachings of his church, but Paliau replied that it was nothing new. Schwartz suggested that some people might think that Government of the Holy Spirit sounded like a cargo cult. Paliau said that he didn't believe in cargo cults and that 'samting em i no kamap nating'that is, you can't get anything for nothing. ${ }^{1}$ Anyway, he said, people would know what he meant and what most people wanted was to grow copra and coffee and send their children to school and that is what he meant by 'kingdom $i$ kam'. Schwartz was not easily put off and suggested again that this kind of language would remind people of the Noise. Paliau replied only that Muli had died in 1976 and 'his work [that is, the Noise] is completely over' (wok bilongen i pinis ologeta).

Schwartz was accustomed to Paliau responding to questions with artful ambiguity, but on this occasion Paliau sounded less intentionally ambiguous than a bit unsure of what he meant. If Paliau was losing confidence, he had reasons. He had helped create the new government, and he was well known to its famous leader, Michael Somare. But he had no prospects for a significant role in that government and the church he created was losing ground. But Paliau now had help pondering his next move. We are reasonably sure that up to the mid-1970s Paliau was the sole author of his teachings and programs. But by 1978 there was an entirely new influence on Paliau's thinking. One thing Paliau told Schwartz very clearly and proudly was that several young men with considerable schooling, even university degrees, and wide experience, including as high government officials, had become his close confidants.

1 Paliau must have known that 'samting em i no kamap nating' can have more than one meaning. It can mean that everything takes physical effort; but it can also mean that no amount of physical effort avails without supernatural aid. 
By the 1960s, many Paliau adherents had come of age almost entirely within the Movement, but too late to take advantage of the expanding access to schooling it helped bring about. Younger Manus generations, however, had been able to pursue formal education from childhood. By the 1970s, many of them were working throughout PNG as teachers, clerks, technicians, and functionaries of the government of an independent country. Schwartz had thought it unlikely that many members of younger, highly literate generations would find the Movement meaningful. He may have been right. We do not have data on the full range of attitudes towards Paliau and the Movement among those generations who went from village schools to high school, technical training, or university. We know, however, that in the mid to late 1970s a few such returned to Manus and became deeply involved in the Movement. Four became especially close to Paliau and important to the Movement. Their names will come up again, so we will introduce them now, in alphabetical order.

Peter Kuwoh rose to the rank of captain in the PNG Defence Force before returning to Manus in the late 1970s to live in Lorengau and work with Paliau. Paliau Lukas (aka Paliau Lukas Chauka) received bachelor of arts degrees in philosophy and economics from the University of Papua New Guinea and served as the first director of the Papua New Guinea Housing Commission (Wanek 1996: 180). On returning to Manus he became partowner of a retail store in Lorengau —Edgell and Whiteley Pty Ltd—as well as a member of Paliau Maloat's inner circle. Martin Thompson Poposui was an attorney who served as legal officer for the Manus Provincial Government prior to devoting himself to the Movement (Wanek 1996: 167). Kisokau Pochapon received a bachelor of arts degree in surveying from the Papua New Guinea University of Technology and served as the first surveyor general of independent PNG. He resigned from that post in 1982 to campaign (unsuccessfully) for a seat in parliament from Manus on behalf of the Movement. He was born and raised in Mbukei (Pokawin 1989: 253), which was a Movement stronghold from the beginning and remains so. In 2015, he was living on Baluan, still playing a major role in the Movement, but he died the following year.

These men stressed that they had received all their metaphysical knowledge from Paliau. But when Schwartz spoke at length with Paliau Lukas and Peter Kuwoh and when Paliau Lukas published his views (Lukas 1983), what they said did not always unequivocally recall Paliau's style. We cannot know with certainty to what extent the four men influenced the doctrines towards which Paliau appeared to be groping 
in the early and mid-1970s. But they were clearly responsible for some major changes in the Movement's public face, for it was in the late 1970s that the Movement began to produce and issue typewritten documents in multiple copies in both English and Tok Pisin. Paliau signed many of these by hand over his typewritten name. Some look as though they are indeed verbatim transcriptions and credible translations of his spoken words. One document more than others, however, looks as though his literate young collaborators contributed to the content. It probably dates from 1981, and-although it is in Tok Pisin-it is substantially longer and more systematic than any other Movement documents of which we know. This is a booklet called Kalopeu: Manus Kastam Kansol Stori. We will return to the meaning of the subtitle later in this chapter. The title, Kalopeu, is the Titan word for the chambered nautilus. As explained to Schwartz, it is an appropriate symbol of the Movement because it is fearless, never retreats, but is never angry, and the Movement should be similarly peaceful but unstoppable. ${ }^{2}$ The booklet is 14 typed, single-spaced pages long. It contains a table of contents (with section titles, but not their page numbers) and several neat, hand-drawn illustrations. According to Otto (1991: 269), although the ideas in the booklet are attributed to Paliau, Peter Kuwoh wrote the text. (We provide an English translation of most of the text from the Tok Pisin original in Appendix B.) $)^{3}$ But before Kalopeu was published, Paliau described to Schwartz the fundamentals of the new creed.

\section{A Longer Story of God: Wing, Wang, and Wong}

On 1 January 1980, in Pere village, Schwartz found Paliau firmly focused on the future and armed with a new historical cosmology. In addition, instead of insisting, as he had in 1978, that his ideas had not changed,

2 According to Wanek (1996: 269), the drawing on the front of the booklet is said to represent a male and female kalopeu attached to each other, symbolising cooperation between men and women in moving forward. To someone familiar with the Admiralty Islands it may resemble more closely the ornately curved handles of a style of wooden bowl common in the Admiralties before the colonial era. 3 The Movement issued another booklet about a year later in both English and Tok Pisin versions. This is a revised version of Paliau's presentation at the 1970 Waigani seminar mentioned in Chapter 12 (Ward et al. 1970: 144-61). Otto (1991: 272) describes how in the booklet the original text of Paliau's presentation was altered to accord with the new Movement doctrines, vocabulary, and chronology. Among other things, Paliau's date of birth is now given as 1893 . As Otto points out, this was likely a deliberate change, as other dates have also been amended to fit the new ideology. 
he now insisted that they were all new. But these were, he said, his 'last teachings'. In Tok Pisin, 'last teachings' is las save, which could also be translated as last knowledge; that is, the last knowledge to be divulged to his followers. Paliau continued: 'It's time to change everything I said after World War II, from 1945-46. Now I'm changing it. I'm changing many things'. He explained to Schwartz that everything he now had to say he had known since he was a child, but the Australian administration had forbidden anyone to disagree with the government or the missions on pain of imprisonment or worse. But now that PNG was independent he could speak out.

Paliau's first new teaching was that there is no God: 'The missionaries speak of God, but there is no God'. There is, however, a creator or supreme being, and Paliau told Schwartz that it is called Wing. Wing lives in the clouds and has no body, Paliau explained. One way to say this in Tok Pisin is that 'Wing $i$ no gat mit', that is, Wing has no flesh. One can also say—as Paliau often did-that 'Wing em $i$ win nating', that is, Wing is like the wind or the breath. This is the sense that dominates depictions and discussions of Wing, to the extent that the creator is often called Win, which in other contexts is the Tok Pisin term for the wind.

A second entity is called Wang, or sometimes Wang Jesus. There is also a third critical entity, whom Paliau calls Wong. In Paliau's new doctrine Wong takes the place of the Holy Spirit in the Christian Trinity. Wing-or Win-created all things including Heaven, which Paliau calls the Second Place; Wing's abode in the clouds being the first. Earth, (in Tok Pisin, ples daun) is the Third Place. Wing created all things, including Wang Jesus and Wong, who are incorporeal like Wing. Some essence of Wing, Wang, and Wong lives in each human being.

Some readers will find the idea of a holy trinity called Wing, Wang, and Wong risible. To many Americans, it may sound like a crude burlesque of a 'primitive religion' from a Bob Hope and Bing Crosby movie, an Abbott and Costello farce, or a Three Stooges film. ${ }^{4}$ Paliau, of course, held that the names were a revealed truth, not a human invention. Numbers of Paliau's followers, however, say that 'wong' also means I, myself, or me in Paliau's Baluan language (cf. Otto 1991: 269n7). And, as noted above, one can see the name Wing as a transformation of win, the Tok Pisin

4 Risibility results partly from unfamiliarity. The Bible, for instance, has given many generations of unchurched, first-time readers hours of fun. 
word for wind, the natural phenomenon most closely analogous to Wing's essence. But whatever else may be involved, the appeal of alliteration-its musicality and its mnemonic power-is also undoubtedly a factor. And it is the only explanation we can think of for naming the second member of the trinity Wang. ${ }^{5}$

As the most dramatic episode in Paliau's new historical cosmology begins, Wang, or Wang Jesus, is the ruler of Heaven and the angels who inhabit it. An angel named Laitsan challenges Wang's authority. Wang banishes Laitsan to Earth where Laitsan becomes Luspa-that is, Lucifer. Luspa continues making trouble by convincing Adam and Even-whom Wing had also created - to disobey Wing. This they do by having sexual intercourse. Until that point, Adam and Eve could obtain anything they wanted—including children — simply by thinking of it. In Wind Nation parlance, they obtained all they desired free-in Tok Pisin, fri. To use Paliau's words, they lived in freedom (in Tok Pisin, fridom) or, sometimes, True Freedom (Tru Fridom). By disobeying Wing, however, they lost their freedom. This is the freedom that characterises the First Order of Godthe world before the Fall. And, because they succumbed to Luspa's or Satan's blandishments, they and all the people of the world now carry something of Luspa within them as well as something of Wing, Wang, and Wong.

The long 1981 printed version of the doctrine includes many variations on the details of the biblical story of creation and its aftermath. The essentials, however, are familiarly Judeo-Christian. Wang Jesus comes to Earth to try to help the descendants of Adam and Eve, is persecuted, predicts that he will rise again, is crucified, and does rise again after three days. He then tells his followers that he will come back again to rule the world when the people of the world are ready for him. But his instructions on making themselves ready are cryptic. Before Wang Jesus goes back to Heaven, he addresses his 'number one disciple', Peter (or, in Latinate mission Tok Pisin, Petrus) as follows: 'Peter, you hold a key to this Earth and I, Jesus, hold a key to Heaven. When you open Earth, I can open Heaven and they can unite'.

5 Opera lovers will have noticed immediately the parallel of Wing, Wang, and Wong with Ping, Pang, and Pong, the royal ministers in Puccini's Turandot. It seems unlikely that this work influenced Paliau, although it is not impossible. 
Paliau also spoke of the Key of Petrus in the 'Long Story of God', but other aspects of the newer, longer story differ from both the Bible and the Long Story. It is significant that in Paliau's new version it is not Australians or Europeans or whites in general who are blocking the path to the First Order or, in the new jargon, True Freedom. Adam and Eve lost the necessary knowledge through their own fecklessness and were tainted by their dealings with Satan. They passed that taint to their descendants-all of humanity-and it is the Satan in them that keeps human beings from recovering the knowledge that would restore Freedom. When Paliau first spoke to Schwartz of the new doctrine, this feature struck Schwartz more than anything else. He immediately pointed out to Paliau that in the 'Long Story of God' Jesus instructs the whites to bring knowledge to the black man but the whites don't do it. Hence, the sad condition of black people. But now Paliau was placing the fault elsewhere. Paliau repeated that his new teaching reflected the knowledge he was obliged to keep secret prior to independence. He explained further that the missionaries didn't tell the truth, but they didn't lie maliciously. They simply didn't know the truth; they didn't know about Wing, Wang, and Wong (in Tok Pisin, Ol i no save long Wing, Wang, Wong).

Otto (1991: 281n21) notes that in the 1980s he encountered people in many parts of Manus who regarded themselves as adherents of the new teachings but who 'still believed that white people had an easy life thanks to their special knowledge which they refuse to share with black people'. But Paliau and those closest to him left no room for ambiguity in their oral and written statements. A vital implication is that since the obstacle to True Freedom is within all people - that is, the taint of Satan - the new doctrine pertains to universal salvation, not just achieving parity with or superiority to whites. The new teachings, Paliau explained to Schwartz, are not just for black Papua New Guineans. They are for everyone in the world. To use a phrase that Paliau and his acolytes came to use over and over again with slight variations, they were for 'all black men and women, all white men and women, all brown men and women' (olgeta blakpela man na meri, olgeta waitpela man na meri, olgeta braunpela man na meri).

In previous decades, many of Paliau's followers had been unsure if whites had already obtained the First Order of God or were stuck at a high level of the Second Order, a condition better than that of the blacks but not as good as things could get. But according to Paliau's new revelation, no one in the world enjoyed the True Freedom of the First Order. No one in the world even enjoyed 'development' (which Paliau rendered as sounding 
something like tipolot). He explained to Schwartz that 'no countries in the world have it, no matter how long they have been independent'. The development that is universally lacking has four parts:

- First, development of the spirit 'that is in the heads of all of us white men, white women, brown men, brown women, black men, black women'.

- Second, development of the body, which is the house of the spirit.

- Third, making money or, in Tok Pisin, wok mani (work money). We will linger on this aspect of development briefly because we are entering the country of ambiguity again. Paliau explained work money to Schwartz thus: 'Where is money? It is hidden in the ground. But it is emerging now. Everything in the ground must develop now. Everything is there to look after us, in the ground and in the sea and on the earth are our mother and our father to provide everything we need'. (In Paliau's Tok Pisin: Mani i stap we? Em $i$ hait pinis i stap long graun. Tasol em $i$ kamap nau. Olgeta samting nau $i$ stap long graun $i$ mas tipolot. Em i gat olgeta samting bilong lukautim yumi, graun na solowara long ples daun i papa na mama bilong yumi bilong karim olgeta samtimg bilong lukautim yumi.) What Paliau does not speak of here is how people can acquire these riches. Given Paliau's interest in the secret of True Freedom it is safe to assume that when he speaks of 'work money' or developing the wealth of the land and sea he is not necessarily referring to the drudgery of growing crops for sale or fishing for the market. In later discussions with Schwartz, Paliau attempted to clarify, explaining that-in the new doctrine-pursuing money through commercial 'wok mani - that is, business - was the way of Satan. Real abundance came through right living and right thinking (cf. Otto 1991: 275n14). ${ }^{6}$

- Fourth, all the world's people must engage in 'good living'. As Paliau explained, 'Good living must emerge; living correctly in the eyes of Wing' (in Paliau's Tok Pisin: Gutpela living $i$ kamap $i$ mas go stret long ai bilong dispela man, em Wing).

6 Although Paliau never wavered from this position, other leaders of the revived Movement sometimes hedged, at least for white audiences. Wind Nation followers on the remote island of Nauna told Wanek that the wealth in the ground would come from what they called in Tok Pisin factori (that is, factories), which would emerge—or re-emerge-with the return of Wang Jesus. But Wanek (1996: 284-5) also reports that Paliau Lukas told him that such rank-and-file members were misinterpreting the new teaching; wealth in the ground, he said, meant only ordinary agricultural or horticultural products. 


\section{Origins of the new doctrine}

References to an incorporeal supreme being that manifests as or through the breath appear to go back to the beginning of the Movement. In accounts of Paliau's telling of the 'Long Story of God' Schwartz obtained in the 1950s, some state that Paliau taught that God animated Adam and Eve with his breath. As noted in Chapter 9, the word 'win', Tok Pisin for wind in most contexts, appears in a Cemetery Cult marching song, although its meaning in that context is not clear. The meaning is much clearer-that God is like wind or win-in one of Paliau's speeches from 1964 in which he proclaimed 'our ability to think is the breath of God within us'. He later elaborated on this to Schwartz as follows: 'God isn't far away. He is here with us, he is like the wind. We can't see him. My tingting is God also. When people die, their tingting are loosed, their flesh goes in the ground. Their tingting are like the wind from God's mouth and they go back to God'.?

Paliau claimed that in his childhood he already understood that the real name for this entity-God-is Wing and that it is the principal figure in the alliterative trinity Wing, Wang, and Wong. However, Paliau's own words suggest that the new ideas did not come to him full blown. When Paliau spoke to Sunday gatherings in 1978 he had not yet repudiated God for Wing; he spoke of 'God papa bilongyumi' (God our father). But Paliau was also using language and images that did not appear in the 'Long Story of God' or his early conversations with Schwartz. He appears, for example, already to have begun to blame Satan and the taint of Satan in Adam and Eve and their descendants for exclusion from a life of 'freedom', placing great emphasis on the condition of Adam and Eve before they yielded to Satan's temptation: everything Adam and Eve wanted was 'fri'.

It is impossible to say to what extent Paliau's enunciation of the idea of a creator analogous to breath or wind is in any sense original. Such an idea is common in the world's religions, including the Judeo-Christian tradition. But Paliau claimed that the name Wing — and its cognates Wind

7 The Tok Pisin third-person pronoun em applies to men, women, and things. In translating, we sometimes refer to both God and Wing as masculine because Paliau and his followers habitually spoke of the Christian God as masculine-as in God papa bilongyumi; that is, God our father-and we have no evidence that when Paliau proclaimed a new supreme being he altered its assumed gender. In some contexts, however, Paliau and his followers clearly treat Wong or the Holy Spirit as a female entity. 
and Win-was secret knowledge, vouchsafed only to him. Whatever the origins of this conception of the nature of a supreme being, Paliau's claim was a bold way to distinguish his metaphysical ideas from those of mission Christianity, something Paliau strove to do from the beginning of his career.

Paliau's new colleagues may well have played a significant role in, let us say, the refinement of Paliau's lifelong secret knowledge. There is no doubt that they aided in promulgating it. By 1980, Paliau Lukas and Peter Kuwoh had joined with Paliau Maloat to create what they called the Study Group (in Tok Pisin, Stadi Grup). Most accounts of the Study Group say it began in or around 1978. Paliau Lukas told Schwartz in 1981 that it began in 1975, when he returned from a trip to Australia pertaining to his government post. Wanek (1996: 195) understood that the Study Group began in 1979. In any case, 'Study Group' sounds distinctly academic or bureaucratic, not like a name of Paliau's devising. This entity probably began as informal meetings of Paliau Maloat with Paliau Lukas, Peter Kuwoh, and a few other young men who had returned to Lorengau from PNG's larger towns. Although Paliau claimed that he had understood since childhood the core ideas the Study Group came to espouse, documents and interviews suggest that they emerged gradually and probably in dialogue with these younger followers. ${ }^{8}$

Typed minutes from a November 1978 meeting of the 'Baluan United Church Lotu Stady', held in Naringel village on Los Negros Island, identify Paliau Maloat as 'Tisa na Plena' (Teacher and Planner) and Paliau Lukas as 'Lotu Stady Siaman' (Lotu Study Chairman), and report that 113 people from 17 different villages attended. The ideas discussed partake of both the old and the germinating doctrines. Whites are still blamed for withholding critical knowledge, but 'the Holy Spirit is in each of us' and the best way to combat Satan-rather than white domination-is

8 Wanek (1996: 218) describes a 1989 gathering in Lorengau, led by Paliau, devoted to stadi. It involved long periods of silent thought about the whereabouts of the Key of Petrus- that is, the Key of St Peter, a mystery Paliau also spoke of in the early days of the Movement (noted in Chapter 5 of this volume). These were punctuated at long intervals by what Wanek calls someone's 'faltering' effort to suggest an answer and Paliau's harsh denunciation of his or her statement as 'rubbish'. According to Wanek (1996: 218), at least one of Paliau's confidants thought that Paliau's physical body was the key because three days after Paliau died Wang Jesus would return, inhabiting Paliau's rejuvenated body and there would then be no more hard work, ageing, hunger or sickness. Schwartz never heard Paliau equating the Key of Petrus with his body's death and resurrection. We are certain that he prophesied his death and resurrection. The Key of Petrus, however, appears to play at best a peripheral role in ideological justification for any Movement activity. 
to cultivate sensitivity to the Holy Spirit's promptings. According to the minutes, the group also decided that 'God' is no longer an acceptable name for the supreme being because it is from the language of the whites.' The alternative proposed, however, is not Wing or Wind/Win; it is lapan tumbuna (approximately: noble ancestor).

From the time of Schwartz's first encounters with members of the Study Group, they insisted they were engaged in study, not lotu. It became clear that what they meant is that they were not engaged in worship or propitiation. Rather, they were seeking direct knowledge of the nature of things to replace the doctrines received from Christian missionaries or recorded in the Bible. Paliau Lukas put this eloquently in a 1984 conversation with Schwartz: 'Did the Bible start knowledge? Or did knowledge begin in men's minds and then go into a book? If it begins in men's minds and then it goes into a book, when my understanding tells me that my study is all right and is true, no one ... can deny it. I don't believe in this Bible. I believe this study is true'. (In the original Tok Pisin: Baibel, em i statim save? O save i stat long het bilong man na i go long buk. $\mathrm{Na}$ sapos $i$ stat long het bilong man na $i$ go long buk, taim save bilong mi $i$ oraitim stadi bilong mi na $i$ tok $i$ tru, i nogat narapela man $i$ ken sensim dispela. Mi no bilip long dispela baibel. Mi bilip long dispela stadi i tru.)

How much did people like Paliau Lukas contribute to the ideas coming out of the Study Group? We can only speculate. We know that some members of the group had strong feelings about naming the creator that may or may not have preceded their intimacy with Paliau. In a 1984 conversation with Schwartz, Paliau Lukas and another Study Group member, Kanaw Kampo, explained that one reason loyalty to mission Christianity had not yielded Papua New Guineans the hoped-for benefits was that the missionaries' God was a foreign entity. 'It isn't ours. [God] is a word in a European language, a white language. So we have to find our own language to call on our ancestors and everything so although they didn't hear us before, now they will.' The previous year, Paliau Lukas had made a similar point in a short article written for a Christian mission publication. He wrote, in English, 'Papua New Guinea is a politically

9 Here and elsewhere, however, followers of the new doctrine insist that Jesus is a name ordained by the supreme being and thus they need not change it. 
independent nation. Religion, likewise, must be independent. We must have our own status; we must have our own views of life and through them develop our own belief and theology' (Lukas 1983: 7). ${ }^{10}$

Paliau Lukas was probably at least partially responsible for the Anglophile monarchism that entered Paliau's doctrine in the 1980s. During his stint as a government official, Paliau Lukas visited England for a course of study. He also saw the sights, including the Coronation Chair that resides in Westminster Abbey. (The Coronation Chair dates from the thirteenth century. It is often called St Edward's Chair or King Edward's Chair. Since the fourteenth century all English and British monarchs-with the exception of Queen Mary II-have been seated on it to receive the crown.) Paliau Lukas spoke at length of the splendour of monarchy one night in 1990 when Schwartz sat up until dawn with a few young members of the Study Group. He spoke of the British royals as analogous to Jesus and God as kings upon their thrones or to the lapan of old Manus society. He seemed unaware that the royal family does not actually rule England and he persisted in speaking of kings, although he knew that the current head of the royal family was a queen. He also said that he had intuited, or it had been revealed to him, that the Coronation Chair was really the throne of King David, magically transported to England, and that the royal family were the direct heirs of Adam and Eve, but were unaware of it. Further, it was the destiny of the royal family to rule a new nation that would extend from England to Manus, with the English monarchy at one end and Paliau at the other. Paliau Lukas reproached Schwartz, as an American, for having rejected the British king, but said that it was not too late for America to become part of the new 'Commonwealth' along with Great Britain, Papua New Guinea, and Australia.

Wanek (1996: 207) points out that the apotheosis of the British royals echoes ideas in a booklet Wanek noticed in Paliau Maloat's possession in the mid-1980s: 'The United States and British Commonwealth in Prophecy' by Herbert W. Armstrong, founder of the Worldwide Church of God, an explicitly millenarian Christian sect. Armstrong's version of Christianity includes the idea that the people of Britain are descendants

10 Paliau Maloat and his close associates had all taken up the cause of Wing before 1983, but Paliau Lukas did not mention Wing in this piece. Instead, he wrote that 'Manus has a religion. We believe in a supreme being, God, and we call him by the name "Lapan"'. To the best of our knowledge, Paliau Lukas's portrayal of an indigenous Manus idea of a supreme being is not accurate. Paliau Maloat and his followers, however, did on occasion speak of Wing as 'Wing Lapan Tumbuna' - that is, translated roughly from the Tok Pisin, 'Wing Noble Ancestor'. 
of the ancient Israelites. The booklet also describes the Coronation Chair in detail. Paliau could have understood very little of the text of the book, which is written in English, but someone could have translated it for him.

Throughout his career, Paliau regularly introduced new ideas or elaborations of old ones to his followers. It appears to have been an effective way not only to connect his doctrines to a rapidly changing larger world but also to keep followers' attention by providing novelty. A degree of Anglophilia was not completely novel in the Movement. Many followers, for instance, attached great importance to the Order of the British Empire (OBE) Paliau was awarded in 1970. Kisokau Pochapon, addressing an audience of Movement stalwarts, once spoke of the OBE as an honour received directly from Queen Elizabeth-an honour that was also a grant of authority: 'The Queen herself saw that this was a man with special knowledge. So she chose him as an officer to watch over the British Commonwealth' (in the original Tok Pisin: Em kwin yet $i$ luk save olsem man hia i gat dispela save. Em i makim em i ofisa long lukautim British Commonwealth). But the occult Anglophile monarchism Paliau Lukas expounded to Schwartz sounds strikingly arbitrary in relation to any aspect of Movement ideology up to this point.

From the start, Paliau had to be flexible to keep from losing personal control of the Movement, including his church. Competition from independent sources of invention or revelation can be a serious threat to any charismatic leader. Within weeks of initiating the Movement just such a potential crisis confronted Paliau; that is, the prophecies of the Noise. Paliau dealt with this in large part by letting people attribute to him what they wanted and biding his time. As long as prevailing readings of events supported people's allegiance to him, he could safely keep a light hand on the reins, as he did until the Noise fell flat. He acted much more openly and decisively towards the Cemetery Cult, but even in that matter he may well have understood that people's imaginations would provide interpretations of events that benefited him up to a point.

By the 1980s, however, the remnants of the Movement did not give Paliau much of an institution to defend. He appears to have reached a point at which he found even weakened leadership of an ever more marginal Movement better than no leadership at all. He could not bring himself to retire, content with his considerable accomplishments and claiming 
credit for a few others. Paliau thus had relatively little to lose by allowing mystical Anglophilia in the door if it brought with it youthful followers with skills in communication better suited for the times.

However it entered Movement ideology, Anglophile monarchism endured. Nothing of it appears in Kalopeu: Manus Kastam Kansol Stori, but when Prince Charles visited Manus in 1984, Paliau and his principal lieutenants tried unsuccessfully to present him with a document advising him that he and his wife at the time, Princess Diana, were the direct descendants of Adam and Eve, that they were destined to rule a new Commonwealth under the protection of Wing, and that the Coronation Chair was actually the throne of King David. As we will see, these ideas moved gradually closer to the centre of Movement doctrine, so that when Smith visited Baluan in 2015 dozens of men were busy preparing a home for the throne of King David a short walk from the house in which Paliau died.

\section{The days of wonder}

Thus, from Paliau and through the innovations of the Study Group, the true nature of the creator, the creation, its tragic aftermath, and the role of the British royal family in a new world came to light. But one vital piece of knowledge remained elusive: full knowledge of how Paliau and the members of the early Movement had once actually come close to attaining the blissful, effort-free condition of the First Order of Godnow construed as the condition of True Freedom that Adam and Eve had once enjoyed.

In 1953-54, some participants in the early Movement (prior to the Noise) described it to Schwartz as a time when life was conspicuously easy. Rather than fade away, such recollections became more vivid over the years, so that when Lungat met Schwartz in Lorengau in 1973 he reminisced about the ease of canoe travel: 'When we sailed from place to place God made our way easy. If today I wanted to go somewhere and tomorrow I wanted to come back, God made it easy for us in both directions', not only calming the sea but sending winds from the right quarters. By the late 1980s, the legend had grown. In 1953-54, Paliau's followers had told Schwartz that the early Movement's days of wonder had ended by 1950 . But according to Kalopeu (translated here from Tok Pisin): 'In 1946-53 all things, such as wind, rain, and sea, together with all kinds of food and game, obeyed what our fathers and mothers were 
saying. From July 1953 until today [1981] all these things no longer obey what is being said'. Members of the Study Group said that their elders confirmed that this state of things had continued until 1953-well into the days of the Cemetery Cult and the coming of the official counciland perhaps even longer.

If life had thus hovered on the edge of True Freedom only shortly before Schwartz and Shargo arrived in Manus with Mead, no one had mentioned it to them. Rather, Movement followers had pined for the tentative grip on the First Order they had achieved several years before. What is important, however, is that its members described the Study Group as an effort to recapture the knowledge that had made possible that fleeting taste of True Freedom. In the words of Paliau Lukas: 'Paliau showed our mothers and fathers how the wind would obey, the lightning would obey, the rain would obey, the thunder would obey, the sea would obey, the fish would obey. Now we're trying to find out what made this possible. Why won't anything obey anymore?'11

The new doctrine held that people no longer have the ability to command the elements because Laitsan/Luspa/Lucifer deceived Adam and Eve. But accounts of the early Movement's days of wonder invariably attribute the ease of life both to Paliau's special powers and-more important-to the remarkable harmony in which Movement participants dwelt. They met together to make decisions, they worked together, and if they disagreed or became angry they settled their disagreements quickly and publicly. In this, they were adhering to the principle of harim tok-which in this context means living according to divinely ordained rules. And, as Paliau Lukas explained decades later, the same principle applies under the dominion of Wing: 'Harim tok em i nambawan oda bilong Wing lapan tumbuna bilong mipela' ('Harim tok is the first commandment of Wing, our noble ancestor'). And when people obey Wing the elements will obey them - that is, the wind, rain, and other elements will harim tok with respect to human beings. But now they have to 'study' to restore this condition 'so it can be easy for us, so all the children that come behind us can get everything free. They will walk in peace and freedom and look after their brothers and sisters everywhere'.

11 The term we translate as obey is the Tok Pisin harim tok-literally, to hear someone's voice or commands. 
Just being cooperative, however, is not enough. People must live in harmony under the authority of Wing, who listens when people call on him in harmony. Schwartz asked members of the Study Group-in Paliau's absence-if they were getting better results from their appeals now that they were calling on Wing, not God, and they reported limited success. Paliau Lukas offered, in English: 'We're seeing signs that harim tok is working for us. The rain pays attention. The wind pays attention for some of us'. And, of course, Paliau can still command the elements, as many people-Study Group members claimed—had seen.

\section{The Manus Kastam Kansol}

We have already made the new doctrines of this phase of the Movement more systematic than we found them in what Paliau and his followers said and wrote. ${ }^{12}$ But we will indulge in this less as we continue and remind readers that lack of system or coherence in ideology has seldom been much of a handicap in either religion or politics. People are especially tolerant of incoherence in metaphysical doctrines, where a certain amount of contradiction and a few conundrums can even add a sense of mystery, suggesting wisdom beyond the normal human ken.

A millenarian effort risks less by incoherence than by neglecting to give people something to look forward to and something to do while they wait for salvation. In the case of Wind Nation, initially it looked like what people should do to hasten the days of True Freedom remained vague. The Movement produced more than one list of rules for proper behaviour, covering aspects of personal conduct and group conduct pertaining mostly to dimensions of living together in harmony. (We provide two of these lists-one of thirty rules and one of twelve rules-in Appendix C.) The list that has endured longest— which we will revisit in Chapter 14-is

12 At least one indigenous observer has also found it difficult to find coherence in the doctrines of the revitalised Movement. In a 1983 publication, Pokawin (1983b: 112) commented: 'the Paliau Phenomenon may be understood in two ways. Firstly, for an outsider, the whole exercise is very simplistic and confusing. The speeches relating to the 1946 movement are aged and stale, while discussions of a religious nature are contradictory, baseless and disjointed. Religiously, it could be regarded as an exercise in bastardising Christianity in an attempt to appear original and indigenous. The only indigenous aspect of it is the people. The ideas, religiously speaking, are not original. Alternatively, it could be argued that one cannot really understand the phenomenon unless one is tuned into the same wavelength as the adherents. The adherents thus are either acting or they genuinely believe in what is being advocated'. 
also the shortest, comprising only five rules. The following is a necessarily rough translation of a Tok Pisin version provided by a Movement leader in $2015 .{ }^{13}$

1. Treat others with respect.

2. Love.

3. Enjoy life with others.

4. Speak the truth.

5. Appreciate life.

As guides to behaviour these dicta leave a lot of leeway for interpretation. And there is certainly no solid scaffold here for a program of mass action analogous to that of the New Way of 1946 . Whether or not Paliau and followers consciously recognised this issue, by no later than 1980 the Study Group had become more activist, spawning what Wanek (1996: 195) calls a 'political wing' called the Manus Kastam Kansol, usually abbreviated as Makasol. A precise translation into English is difficult. Kansol appears to translate neatly to council, although we have seen how council has been a politically controversial concept in Manus history. The Tok Pisin word kastam in some contexts is a cognate of the English words custom or tradition, but for Makasol it signified a highly specific notion of tradition. ${ }^{14}$

13 We say a 'necessarily rough' translation because such single words and brief phrases taken out of context often convey relatively little. The first rule-'Lukstret' - poses special problems. We have seen it construed (within the Movement) as an admonition to respect parents, kin, and leaders. Anthropologist Graeme Humble recently conveyed to us a complementary exegesis from a Manus friend (Reeves Papaol) that supplies what may be essential context. In Papaol's words: 'Lukstret or Look Straight-is a term derived directly from the colonial regimental morning assembly of villagers by their tultuls and luluai in [New Guinea islands] and kiaps in the highlands. They would stand in line just like in the military with the plantation managers or local administrators leading out in front often on an elevated pedestal with flag raising ceremony and morning toksave [that is, announcements] of the communal task for the day. The command to lukstret ['eyes right', 'level eye', 'right dress' are similar commands] is to demand absolute attention'. Papaol suggests that the admonition thus implies giving respect through paying strict attention to authority and acting in unity with the group. 'Love' (in Tok Pisin, lave) always requires interpretation for specific situations. The Tok Pisin version of the third rule is 'pilai', which translates literally as 'play'. Other Makasol materials suggest that 'Enjoy life with others' is an adequate rendering. 'Speak the truth' is a direct literal translation of the Tok Pisin 'tok tru'. The Tok Pisin version of the fifth rule with which we are working is amamas, which translates literally as 'celebrate', but other Makasol materials suggest that 'Appreciate life' is closer to the mark. In Chapter 14, we present a version of the five rules from Mbukei Island that demonstrates their malleability.

14 In the anthropological literature, the Tok Pisin term for this concept is usually spelled kastom. We are using the usual Manus spelling, kastam. 
The Makasol position was that Paliau deserved credit for most of PNG's great leaps forward, most of which had since been undermined. Makasol rhetoric repeats this tirelessly. An inside page of Kalopeu, for instance, displays a black and white photo of Paliau and his wife in indigenous dress-probably taken at the 1973 event at which their appearance so clothed surprised Schwartz-above a statement that Paliau is the father of the Manus Local Government Council, the father of the Pangu Party, and the father of Papua New Guinea, 'now an independent nation'. (In the original Tok Pisin, papa bilong Manus Lokol Gavman Kansol ... papa bilong Pangu Pati ... papa bilong Papua New Guinea, nau i Independen Neisen.) Makasol's hyper-jaundiced view of things is also displayed in a typed document, in both Tok Pisin and English, that a Makasol member gave Schwartz. It is dated 1982 and signed in Paliau's hand over what had become his title: OBE, Last Prophet Long Wold-that is, the Last Prophet of the World. Paliau declared himself the Last Prophet no later than 1984. ${ }^{15}$ Some variation on Paliau's full title (such as OBE, Esquire, Last Prophet of the World) appears on nearly every Movement document from 1984 on. Being against something provides lots of opportunities for action and in the breadth of its antagonisms the following document is one of many that give Makasol members a lot to oppose. Among the things it declares against some are imaginary, but some are the very stuff of the improved way of life Paliau had once worked for, such as more indigenous participation in government and better government services. The document calls for 15 things to be removed from Manus Province and for 'Manus Province, New Guinea Islands, New Guinea, and Australia to become one country, and to unite with London to form one Nation'. ${ }^{16}$ Here is the title of the document and the list of things to oppose in the original English version (and original spelling):

THE PAGAN DEPARTMENTS BY TODAY'S DEFILED
GOVERNMENTS THAT ARE DETERIORATING
MANKIND IN THIS WORLD

1. God-worshiping Churches

2. Youth Groups

3. Rascals

15 The date on our document, 1982, may be incorrect. Other accounts (e.g. Otto 1992a: 62; Wanek 1996: 211) report that Paliau declared himself the Last Prophet in 1984. The exact date, however, is not very important.

16 It isn't clear if New Guinea is intended to include what had once been the separate entity of Papua. The New Guinea Islands usually refers to the arc of PNG islands sometimes called the Bismarck Archipelago. 

4. Cowboys
5. Communist Government
6. Provincial Government
7. Community government
8. Hospitals and Aid Posts
9. Education
10. Women's Council
11. Corrective Institutions
12. All Policemen
13. All the Magistrates
14. Communist Laws
15. Factories

It is clear in wider context, of course, that people must reject 'Godworshipping churches' because they should turn to Wing. 'Rascal' and 'Cowboy' are PNG slang of the day for delinquent young people, and we can guess that opposition to 'Youth Groups' and a 'Women's Council' reflects a concern that such institutions might undermine the ersatz form of traditional authority the Movement would soon propose.

Opposition to community government shows Paliau and followers still pushing against the political changes that were leaving them behind. The main theme of such changes was decentralisation, but the problem for Paliau wasn't decentralisation per se but the fact that as put into practice it continued to erase his success in the older system. We described in Chapter 12 how, by 1973, a shifting formal government structure had marginalised Paliau. But that wasn't the end of it. As Otto (1991: 190) summarises:

The Manus District Area Authority ... was transformed into the Interim Provincial assembly in 1977. Two years later the Manus Provincial Government was officially instituted. The province was divided into 15 constituencies which each elected one representative to the Manus Lapan Assembly, the representative legislative body of the provincial government. The provincial government had assumed all powers and functions of the local government council, which thus became redundant. In 1980 fresh elections for the council were still held, but the provincial government was already making preparations for an alternative form of third level government: the community government. The abolition of the local government council was finalized ... in April 1982. In the following years 15 community governments were established corresponding with the areas of the 15 provincial constituencies. 
Paliau made one more electoral effort and in 1979 won a seat in the first Manus Lapan Assembly as representative of the Balopa constituency, which comprised Baluan, Lou, and Pwam islands. But in the 1983 elections he lost his place to a former colleague, the retired headmaster of the Baluan primary school (Otto 1991: 190n7; Wanek 1996: 194). He was now completely out of electoral politics. Further, he and his close followers regarded abolishing the local government councils as an attack on one of the Movement's principal accomplishments. Further, whether by accident or design, the division of the province into community government units split Movement areas among several community governments (Wanek 1996: 197). This was a good reason for Movement hostility to community government. Exploiting - ingenuously or with calculationthe prevailing tendency to attribute significance to homonymy, Makasol rhetorically equated community government with communism, Russians, the Indonesians, and the forces of evil in general. The result was that Paliau and Makasol came to oppose the provincial government as the Movement had once opposed the colonial government. Paliau and his principle followers began to malign the government not merely as a usurper but as the government of Lucifer/Luspa. ${ }^{17}$ This helps account for the call to remove all the government institutions they once coveted, from police and magistrates to schools and health services.

The Movement's new dispensation gave people direction for the future. It also sought to revise the past. An account of Paliau's trial for agitating against the government in the 1950s - an account still circulating in 2015-must have been prepared no earlier than the mid to late 1970s, when the Study Group and Makasol were forming, because the earliest written version we know of is typewritten and presented in both Tok Pisin and English. Not only English, but the English of people with experience beyond the village (for example, the Tok Pisin kiap, meaning government official, is rendered as 'bureaucracy'). No accounts from

17 Regarding the Paliau attitude to community government, Otto's (1991: 190-1) speculations are relevant if not conclusive. Otto argues that although enacted in the name of decentralisation, community government tended to strengthen the national central government: 'The officially stated aim of community government was to give local people a greater say in the government of their own place. While it certainly effected some progress in this direction, it also extended the sphere of the state in Manus villages by giving more people a vested interest in its continuation. It thus consolidated the development which started with the incorporation of the Paliau Movement by the colonial state. The gradual increase of indigenous participation in government culminating in national independence went hand in hand with the expansion of the state as an organization-resulting in greater state influence on the daily lives of villagers'. On decentralisation and community government in PNG as they relate to Manus, see also Pokawin (1983a) and Wanek (1996: 70-6). 
the 1950s, including those Paliau gave to Schwartz in private, resemble this in the least. If Paliau had spoken like this to the examining officials, it is unlikely he would have been treated leniently. The revised version, however, projects Paliau's vehement anti-government credentials into the past. It shows him confounding the examining court by answering with a forthright 'Yes!' to 16 of their questions. The legend holds that Paliau's staunch resistance confounded the authorities so much they gave up and released him. The questions, in the English version, are:

1. Did you want to get rid of the Australians?

2. Did you want to get rid of Australian administration?

3. Did you want to stop all your people from going to school?

4. Did you tell your people not to work for any white men?

5. Did you tell the people of Manus to give all their savings and war damages to you to hold for them?

6. Did you tell your people not to go and see the white men's doctor?

7. Did you tell your people that those who disobey your orders must receive punishment?

8. Is it true that you do not take heed of the luluai's leadership in villages?

9. Did you say that you will be the king, government, and bureaucracy?

10. Is it true that you won't pay the court fines?

11. Is it true that you tell our people not to put their money in the bank and not to spend their money in the general merchant stores?

12. Did you say that you will disrupt the working of the colonial government?

13. Did you say you want to unite the people of Manus under your own leadership?

14. Did you say you want to fly your own flag?

15. Did you say you had no intention of asking the Australian administration for employment?

16. Did you say you do not want the Australian under your plan? 


\section{The Makasol alternative}

From about 1946 to 1973, Paliau excoriated the ways of the ancestors as 'bullshit' (in Tok Pisin, bulsit) that had wasted time and energy in endless ceremonial affinal and mortuary exchange, playing with valuables that were worthless for acquiring European goods. He also condemned the rank structure and the ethnic and ecological groupings of the past. The goal of change was modelled on his and other indigenes' construal of European life in its colonial and wartime manifestations. Now, however, Paliau and Makasol turned their iconoclasm against the emerging approximations of a more European life. They began to exalt the ways of the past, but they depicted them in a highly selective and largely imaginary way. They found reason for clashing with ruling politicians and parties on many specific issues, but the foundation of their opposition was the contention that the government-even though it was a government of an independent state; run by indigenous people; and elected, within the limits of the circumstances, by indigenous people-had usurped the legitimate power of the people. And, Makasol claimed, the legitimate power of the people had been in force under the Local Government Council system.

Paliau Lukas's views were in line with those of other Makasol members, although better expressed (translated in what follows from the original Tok Pisin). In conversation with Schwartz, he described Manus under Paliau's leadership as the 'teacher' of PNG and Paliau as the 'founder of the nation', the person who had brought independence. But as the result of changes in the government since the time of the Local Government Council, 'the people's power has been given to the national government ... now this power must go back to the man who started it', that is, to Paliau Maloat. Paliau Lukas explained further that restoring Paliau Maloat's leadership was only the 'first round'. The second round would be returning power to the council wards. The third round would be instituting 'the government of Jesus, who instituted it in Heaven, and now it must come to Earth. Government of peace, freedom, and living under the order of Wing'.

Other Makasol activists described the kind of government needed in different ways, but the theocratic theme is consistent. For example, in a speech in April 1987, Kisokau Pochapon declared: 'There is one good government, namely that of Adam and Eve in the early days. The rule of this government was that human beings must not grow old or become 
sick, they must not die or be hungry and they must not toil. There shall always be freedom. Our present government does not have this kind of government or rule. Therefore I move that we want to go back to the government of Adam and Eve: we want to live for ever and ever' (Otto 1991: 276). ${ }^{18}$

Makasol brought this ambition down to a more concrete level. Young members told Schwartz that they had to go back to the way of the lapan - the respected leaders of olden times, when-allegedly-everyone obeyed their leaders and moved as one at their command. There used to be harmony, solidarity, coordination, and obedience to leadership, they said (cf. Schwartz 1993: 534). Makasol called this way of life kastam -as in Manus Kastam Kansol. They did not propose or intend to go back to ceremonial exchange, the old ghost-centred practices, or most of the rest of what people remembered or maintained of pre-European life. But the old obsession with ghosts persisted strongly in certain contexts. Many people sympathetic to Makasol were reluctant to neglect certain kinship obligations, for instance, for fear of offending the ghosts. But Paliau and the Makasol inner circle excluded such practices from the official definition of kastam. Neither did they include in kastam the blessing and cursing power of the father's sister.

There is a lot of literature on the importance of concepts similar to Makasol's kastam (and with similar names, due to parallels among Pacific creoles or lingua franca) in the contemporary Pacific Islands (e.g. Jolly and Thomas 1992; Keesing and Tonkinson 1982; Lindstrom and White 1994; White and Lindstrom 1993). ${ }^{19}$ Despite similarities, their local implications vary. Otto (1991, 1992a, 1992b) writes of kastam in Manus from the vantage point of Baluan, but he uses the term in a different and broader sense than we do (cf. Wanek 1996: 111-33). Schwartz first heard people speaking of kastam in Manus in the 1970s. ${ }^{20}$ What Manus people then called kastam was far from an unedited version of indigenous

18 Otto's quotation is a translation from Tok Pisin.

19 In the anthropological literature, the Tok Pisin term for this concept is usually spelled kastom. We are using the usual Manus spelling, kastam.

20 Schwartz (1993: 517-18) describes how the Australian administration contributed to the development of the idea of kastam in Manus by, for example, encouraging schools to include attention to indigenous culture in their curriculums and sponsoring 'shows' of indigenous-style music and dance (cf. Otto 1991: 232-53). 
life. Neither was what Makasol labelled kastam. Rather, it was 'singularly ideological, political and focused on limited specific areas' (Schwartz 1993: 515) of special significance in Makasol ideology.

When the Movement started over, in a sense, after post-independence exclusion from power, Paliau the former iconoclast indulged in performing versions of traditional dance, wearing traditional regalia. But Makasol kastam centred almost entirely on a heavily airbrushed depiction of the past in which people obeyed the directives of their leaders and were not 'bigheads' (in Tok Pisin, bikhet), as they had now become. Makasol ideology also held that such kastam prevailed during the years of the Local Government Council, the restoration of which became a political goal, even though the contrary facts of the case could not possibly have been lost to memory.

\section{Wing Militant I: At the polls}

Makasol engaged in legal challenge, direct action, and electoral politics. In 1984-led by attorney Martin Thompson Poposui-Makasol successfully sued the provincial government for violating the freedom of worship clause in the national constitution by allegedly suppressing Makasol access to the Manus government radio station. Around the same time, Makasol activists occupied government property in Lorengau, claiming that it had been purchased in 1951 with council funds which were in fact Paliau Movement funds. Makasol lost the case (Wanek 1996: 194-5).

In electoral politics, Makasol looked beyond Manus. In 1982, both Paliau Lukas and Kisokau Pochapon, who had retired from his post as the country's surveyor general for this purpose, ran for seats in the national parliament in the second post-independence parliamentary election (the first was in 1977). Makasol endorsed both candidates. At least in this instance, it tried to act like a political party, although it had no presence outside Manus. Some observers called it the Makasol group (Pokawin 1989). ${ }^{21}$ According to Pokawin (1989: 253-61), both candidates depended on what Makasol leaders told them were 10,000 Makasol-inclined voters

21 Makasol fashioned itself briefly as the Makasol Party. But, according to Wanek (1996: 195), it dropped 'party' in 1982, 'because Paliau Maloat felt that "party" was unworthy of a movement like Makasol, which builds on prophecies from Above'. 
in Manus. At the time, however, the total population of Manus was just shy of 26,000 of which about 16,500 were eligible voters. Neither Makasol candidate prevailed.

The next elections for seats in the national parliament were held in $1987 .{ }^{22}$ By this time, community governments had been established and an angry Paliau asked his followers to boycott the election. But both Paliau Lukas and Martin Thompson Poposui ran anyway. Neither won a seat. Martin Thompson Poposui did win a 1991 election to fill a seat that had become vacant between elections, and he retained this seat in the 1992 general election (Dalsgaard 2009: 104). New national legislation soon eliminated the position of provincial premier, held by Stephen Pokawin, an open political opponent of Makasol. As a member from Manus, Thompson Poposui was appointed interim governor (the provincial leadership post with which the legislation replaced that of premier), to serve until the next election. But Thompson Poposui, the most successful Makasol politician, died in 1996 (Dalsgaard 2009: 106). Pokawin won the subsequent election and became provincial leader under the new system. Thompson Poposui's death (at approximately the age of 40) cut short not only his political career but also Makasol's political participation at the national level.

\section{Makasol motives}

It looks like Paliau Lukas and Thompson Poposui may have put political ambition ahead of loyalty to Paliau Maloat in the 1987 election. In that vein, some observers have wondered if they, and perhaps other young Makasol activists, were exploiting Paliau's occult hold on his followers to pursue secular political power. Wanek was acquainted with Paliau Lukas and characterises his views as follows:

Paliau Lukas perceived Makasol as a movement which used 'religion' mainly as a tool in order to make villagers understand the movement's goals, which were purely political. Additionally, 'religion' exerted a certain protection against persecution from the authorities because freedom of worship was granted by the National Constitution. He [Paliau Lukas] emphasized repeatedly

22 In the interim, a few Makasol members obtained seats in the provincial Lapan Assembly (Wanek 1996: 195), but we have no information on their influence there. 
that 'cargo' was of no importance in Makasol. It was quite silly to believe in these sorts of lies, indeed he claimed that the 'cargo' argument was only used by the enemies of the movement to discredit it. (Wanek 1996: 186)

Otto (1992a: 64) writes that 'the Makasol [historical] narratives were used to mobilize lingering millenarian sentiments for party political purposes'. Pokawin (1989: 260) comments: 'critics of the Makasol group call [Paliau Lukas], and others such as Kisokau Pochapon, political opportunists who use the village people for their own political gains. There is some [Pokawin's italics] substance to this view'. Pokawin does not give evidence for the latter judgement. And just a few sentences earlier he suggests that Paliau Lukas's motives are more complicated: 'Lukas is hard to understand. $\mathrm{He}$ is either driven by a higher ideal or is a confused simpleton. Given his academic credentials, I want to think he is driven by a higher ideal'. ${ }^{23}$

Schwartz's extensive conversations with Paliau Lukas and other young Makasol leaders left him with the impression that, if they did not place their full faith in Paliau's cosmology, his construction of history, his personal powers, and his special relationship with Wang Jesus, they were trying very hard to do so. Paliau Lukas eventually broke with Makasol. The direction he took may be telling. Rather than seek an obvious way of entering electoral politics, he became active in the Evangelical Church of Manus. A prized convert, he gratified the church by making the rounds of Manus villages presenting himself as a recovering cultist who, in the Evangelical Church of Manus, had found the truth. Kakak Kais (1998: Chapter 3) notes three other prominent Makasol activists who quit during the same period who also became active in the Evangelical Church of Manus. A fourth became a leader in a Catholic Charismatic group. Kisokau Pochapon did not impress Smith as an opportunist-at least not one with grand ambitions. By 2015, he had been almost wholly occupied with Makasol and its successor, Wind Nation, for decades without, to Smith's knowledge, using his position in these manifestations of the Movement to any obvious political advantage beyond Manus.

23 Pokawin apparently would like to believe that academic credentials inoculate one against becoming a 'confused simpleton'. History in general, however, does not bear this out. Neither does the history of millenarianism suggest that accumulating academic degrees makes one immune to its appeal. Pokawin's own academic credentials are impressive. Among other things, he holds a master of arts degree in political science from Canada's McGill University and served as chancellor of the University of Papua New Guinea for several years post-2000. We do not know his religious affiliation, although he would be a rare Papua New Guinean if he had none. We know that his father and mother were very active in the Evangelical Church of Manus. 


\section{Wing Militant II: For the world}

We have already pointed out important universalistic elements in Paliau's new doctrine-in particular, formal absolution of whites for not sharing knowledge with New Guineans (although many of the rank and file were not fully convinced of this) and calling for True Freedom for people of all races. When still within the fold in the mid-1980s, Paliau Lukas explained to Schwartz that currently nobody on Earth could go to Heaven because Jesus forbade it until all were ready and that freeing all people was thus part of the Makasol mission.

There is some precedent for such universalism in Paliau's earlier teachings. He had always spoken of God as the God of all, whose efforts to help the blacks the whites had thwarted. And he and his followers had occasionally used a formula of multi-racial unity under one god that became standard in the new metaphysics, as Lungat put it in a 1973 conversation with Schwartz: 'We are all brothers. We're white, we're red, we're black, we're brown. All colours live here on Earth. But one God is our father'. But it is also easy to understand why Paliau and his lieutenants began to stress universalism more as they were developing a new doctrine: opposition to white domination is a weak rallying cry for opposing a black government - that is, the government of independence. Opposition to the independent PNG government would not necessarily exclude opposition to international white domination, but that was not the Makasol position.

Since around the beginning of 1990, the Movement has gone by the name Wind Nation-in Tok Pisin, Win Neisen. Adherents have explained its meaning to Schwartz and Smith in three ways that are not mutually exclusive. To wit: Wind Nation comprises the essence of Wing, Wang, and Wong within each person; Wind Nation comprises all the adherents of Wind Nation doctrine; and everyone in the world is part of Wind Nation, whether they know it or not, because Wing dwells in them all. This last idea supports Wind Nation's assumption of worldwide importance. Wind Nation documents often refer to Win Neisen long Wold; that is, Wind Nation Worldwide. Wind Nation also produces its documents on a 'WIN NEISEN LONG WOL' letterhead. During Paliau's lifetime the letterhead frequently included post office box and telephone numbers in Lorengau for 'Paliau Maloat, OBE Esquire; Win Neisen long Wol'. In addition, at top centre, dominating the page, was often the Wind Nation logo, elaborate but inexpertly drawn. 


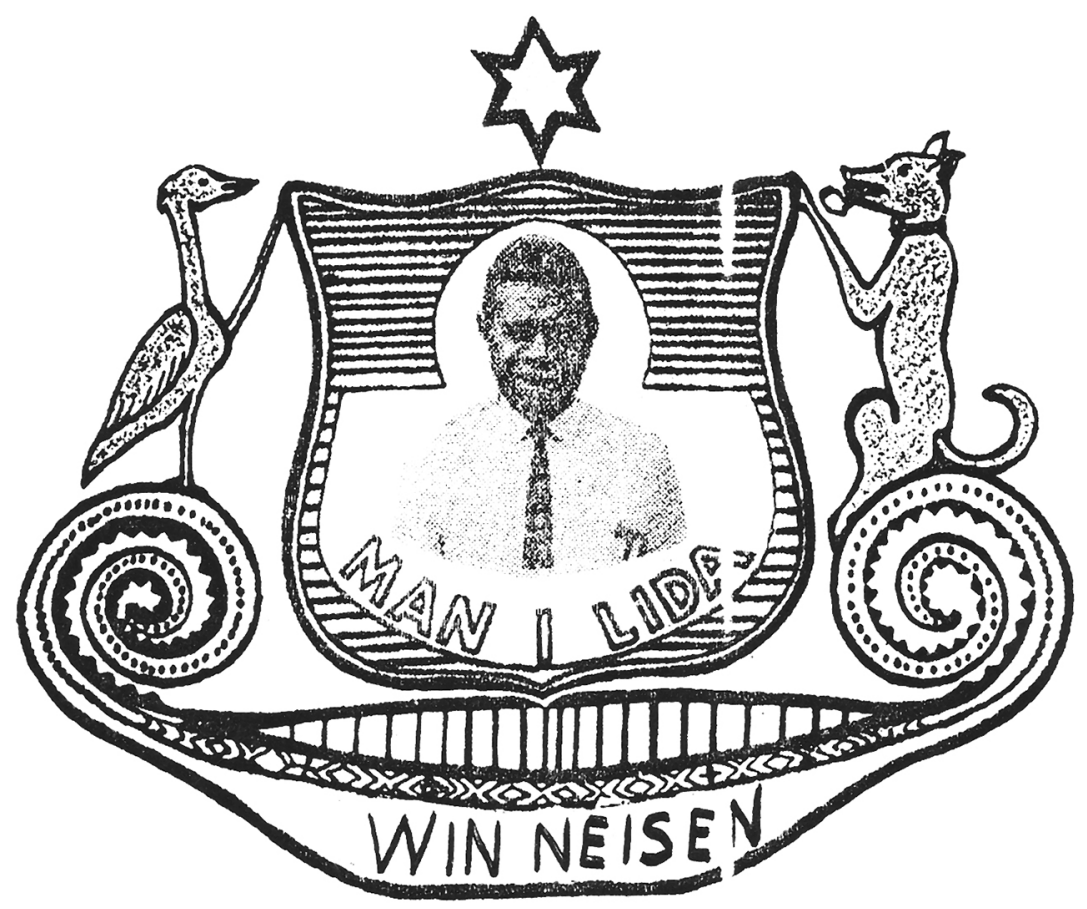

Figure 13.2: In the 1980s, Wind Nation began producing written documents bearing the elaborate but inexpertly drawn Wind Nation logo.

Source: Unknown Wind Nation adherent.

The logo is organised around a shield shape framing a badly copied black and white photo of Paliau in shirt and necktie. Beneath his picture are the words 'MAN I LIDA' ('The Leader'). Atop the shield is a six-pointed star. The shield sits atop a traditional Manus wooden bowl with an elongated shape, like a rugby ball or an American football (that is, prolate spheroid), and large spiral handles at each end. Some Wind Nation members say that the spirals represent kalopeu, the chambered nautilus, a symbol of Wind Nation. The bowl bears the words 'WIN NEISEN'. There is an animal standing on each spiral handle of the bowl. On the right is a dog sitting with its front paws resting on the shield and a pipe in its mouth. On the left is a long-legged and long-beaked bird, with one foot resting on the shield. The dog represents Paliau's small pet dog, which people thought wonderful because Paliau had taught it several tricks, like holding a pipe in its mouth. Maybe they took Paliau's rapport 
with his dog as an example of his alleged control over nature. The bird is undoubtedly a chauka bird (the Manus friarbird), a bird endemic to Manus. It has a loud and distinctive cry that people say heralds morning and evening and warns of danger.

Wind Nation leaders offer adherents both something immediate and something more distant that might or might not embrace the whole of humanity. Speaking at a Christmas Wind Nation gathering in Lorengau in 1990, Kisokau Pochapon seemed to promise his audience a version of the cargo if only they would accept Wing/Win as saviour. Here are his words, translated from the original Tok Pisin: ${ }^{24}$

Follow Win Nation! Wing says that the path to money is easy. It goes through Win. The work of the government, of freedom is with Win. Car, radio, and everything you want-Win. Win makes it happen. Win makes everything here easy to obtain. Win leads on the path to where there is no ageing, no illness, no death. If you want money, if you want a car, whatever you want, Win will give it to you. ${ }^{25}$

But concrete descriptions of Wing's and Wind Nation's government make it sound less than ready to oversee worldwide salvation. At the same gathering at which Pochapon promised easy access to anything people wanted, Paliau-now within less than two years of his death-depicted the government of Wind Nation. The Local Government Council, he said, 'is the freedom government to take care of all of Manus, the true government of Wind Nation is the Local Government Council'. Further, 'Wind Nation is the true nation to bring freedom to all the countries of the world'. Paliau also outlined Wind Nation's 'worldwide structure'. This included a list of officers, with Kisokau Pochapon as president and Peter Kuwoh as deputy president, followed by a hierarchy that reaches down to village-level tax collectors, teachers, and 'councils'. (On another

24 Schwartz was not present at this event, but a Wind Nation leader recorded the speeches for him. 25 In the original Tok Pisin: Bihainim win neisen! Em $i$ tok long rot bilong mani i stap isi. Em i stap long Win. Wok bilong gavman, long fridom, em i stap long Win. Ka, na radio na olgeta samting yupela $i$ laikim hia, bilong Win. Win i wokim. Win i wokim olgeta samting hia na bilong isi bilong en $i$ kam long han bilong yufela. Win i soim rot long noken lapun, no ken sik, no ken dai. Sapos yu laikim mani, yu laikim ka, yu laikim wanem, wanem; Win bai i givim long yu. 
occasion, Wind Nation issued an organisational chart for this hierarchy.) This does not seem adequate to governing the entire world, but fervent Paliau followers probably were not concerned with such details. ${ }^{26}$

\title{
Wanek (1996: 216) reports a Wind Nation doctrine of less universal beneficence:
}

\begin{abstract}
'Wind Nation believes that Wang Jesus will come a second time; this time to Manus, to the coloured people who have not participated in his crucifixion ... But he will not bring them save [Tok Pisin for wisdom or knowledge], because this has already been spoilt by the white man. He will bring tinktink [Wanek's rendering of the Tok Pisin word we render as tingting] to the coloured people, the power of understanding. Using tinktink, things will just happen, in the same way as during the First Order of Things. Adherents of Wind Nation will be able to live without drudgery. Wang Jesus ... will make them heavenly blessed, whereas the white man will continue to be wicked and unhappy, will have to attend schools, and will set out killing other human beings by means of save and weapons'. This doctrine supports Wind Nation's antipathy to formal schooling in the 1980s. It also expresses persistent but unsurprising antipathy toward whites, despite repeated declarations of racial unity under Wing. ${ }^{27}$
\end{abstract}

26 In this speech, Paliau also spoke of the Wind Nation International Bank 'Manus Headquarters'. We know very little about this phenomenon, but Wanek (1996: 196-7) obtained information on what might be the same thing under a different name: 'The Paliau Bank gained importance ... in the late 1980s and members of the movement deposited their individual savings there, after withdrawing them from the Lorengau branch of the Papua New Guinea Banking Corporation. They did this in protest against the system of community governments ... and the Paliau Bank earmarked their money, once again, to fund a new government [the government of Wang Jesus]'. Supposedly the bank had branches in several villages. We (Schwartz and Smith) have not tried to follow the money that may or may not have passed into or through the Movement. We can offer only the following items. Early in the Movement, Paliau collected money-much of it allegedly from war damage payments to Manus people - to support building schools and other infrastructure. In his 1970 presentation at the Waigani Seminar, Paliau said that the war damage fund was used as 'the initial operating revenue for the Baluan Local Government Council during the financial year 1950-51. It was also used to build village schools, aid posts, and cooperative society stores and other things' (Maloat 1970: 151). According to a 1974 Movement document, the war damage fund at that time still contained some 20,000 kina (the currency of independent PNG). Pokawin (1983b: 110) reports there was a 'Makasol Memorial Fund' that in August 1980 contained 6,125 kina obtained from member contributions. 27 Unfortunately, here (and sometimes elsewhere in his otherwise informative book), Wanek does not tell the reader from whom or whence he derives his statements of Movement doctrines or beliefs, so it is impossible to tell if they represent Paliau's pronouncements or have another source. 
Neither Schwartz nor Smith have come across the doctrine Wanek describes. But Wind Nation leaders have often enunciated a doctrine of universal salvation that nevertheless has a dark side - the threat of an apocalypse that destroys non-believers. The most vivid description of this danger of which we know-one that also articulates some expansion of basic Wind Nation cosmology—is in a letter Paliau Lukas sent to Schwartz, then in California, in December 1990. Lukas stresses (in English) the danger the world faces:

The world is heading toward its early stage or its beginnings towards the year 2000. What really is going to happen there in America, California and all of the United States will one way or another affect Manus most. Because Manus is so small and Beautiful in our hearts and minds, Ted, tell the world not to destroy it but to SAFE Manus ... Therefore Ted I now conclude to say world and United States must declare that Paliau Maloat in Manus is our SAVIOUR by December Christmas 1991.

Paliau Lukas enclosed a document written in English and undated, but attributed to and signed by Paliau Maloat, explaining this danger in terms of the cosmology of Wing, Wang, and Wong. Here it is, uncorrected for spelling or punctuation: ${ }^{28}$

I, PALIAU MALOAT, O.B.E. THE LAST PROPHET, wish to reveal to every individual of this World that;

The 'Cloud' is not just an ordinary mass of visible condensed water-vapour, floating high above general level of the ground in motion. It was 'the home', of the invisible creator, Wing and the first ever nation. In it Wing the creator, created five powerful beings; they are:

\section{HIGH STRONG WIND \\ 2. RAIN \\ 3. LIGHTNING \\ 4. THUNDER \\ 5. RAINBOW}

These five supernatural beings are based in the Clouds today as the World know and fully realise. I wish to correct Scientist theory that the five elements are not just mere particles of any sort.

28 The personification of natural forces here is even more extreme than that implied in accounts of Paliau's ability to control them as though they were sentient entities that could harim tok. 
It was through creation that Wing the Creator created and left them as inhabitants of the Cloud.

Subject to the creators own power, a second nation was createdThe Heaven. The Creator left the Clouds and lived in Heaven. The Heaven became his new home. With him he brought three invisible Spiritual Children whom he thought as would become the inhabitants of Heaven. He named his three Spiritual Children as;

1. WANG

2. HOLY SPIRIT and

3. ANGELS

With his own power his three invisible children were respectively symbolized by creating three lights;

1. MOON

2. STARS, and

3. SUN

The Moon symbolizes Wang the first child, the Stars the Holy spirit, the second child and the Sun the Angels, the third child. With the second and third children, the creator Wing ordered their existence to multiply in great numbers, therefore billions upon billions of Holy Spirit and Angels came into being. The Holy Spirit and Angels appointed Wang as the head of government and 'Light of the Sun' [in Tok Pisin, laitsan] as the King. Wang became the government and 'Light of the Sun' became the King of Heaven. The Holy Spirit and Angels became the main work force of the Government of Heaven.

Wing then created the planet Earth. He ordered the Clouds together and thus the clouds formed and shaped what is known today as the earth. The earth with its own environment and characteristics was established and again Wing divided the earth into two parts, the Sea and Land. The sea symbolizes the female generations and the land the male generations, which were already created in Heaven through the Holy Spirit as females and the Angels as the males. Therefore, the sea became the mother and the land became the father of all kinds of life on earth thereafter.

On the planet earth Wing created an additional five supernatural beings. They were to be the supporters of those already created in the clouds thus making the total to ten (10). 
On earth, the sixth super natural being was the Sea, the seventh being very strong currents caused by Tides, the eighth Being Tidal Waves, the nineth being the Earthquakes and the tenth being all particles, substance and anything in material form ...

In our times we could refer to these ten supernatural beings as supernatural powers. These ten supernatural powers can destroy the whole World. Not one country of this world could direct and control these supernatural powers to do as it wish.

The only person who can direct and control these forces is Wang whom the Christians call Jesus Christ. The power to direct and control these forces remains the sole responsibility of that one person. Although invisible he remains the Government and King of Nations of the Commonwealth. Through him he has chosen England as the Nation of the Nations and the Leader of the Commonwealth.

His warning to the World is that every country of the World are now under the power of God as King and Satan as the government. The whole World is in fact being misled by a false creator GOD and SATAN. The truth about WANG JESUS the World does not know. Therefore Wang Jesus is now prepared to use this ten supernatural forces to destroy any country of the World which does not come under his reign-Nations of the Commonwealth.

I challenge all persons of Manus, New Guinea Islands, New Guinea and the World to take heed of this warning.

Thank you very much.

[Paliau's signature]

PALIAU MALOAT. O.B.E.

Last Prophet of the World

\section{Paliau the prophet}

This was hardly Paliau's first venture into prophecy (if, indeed, Paliau composed this prophecy independently). In 1984, he declared that something would happen around the end of 1990; that is, in seven years-a figure Paliau used explicitly to invoke the biblical Joseph's prophecies to Egypt's Pharaoh. Everyone, he said, should join Makasol to prepare for whatever was coming. Just what would happen Paliau left vague, but he implied that a global apocalypse of some kind was 
a possibility and that those who placed themselves under Makasol's protection would be saved. The return of Wang Jesus to rule the world was another implied possibility (cf. Otto 1992a: 62).$^{29}$ Gustafsson (1995: 80) reports that in the late 1980s Paliau 'would say repeatedly that the last day was near and there was not much time left for those who wanted to experience Win Neisen'. That is, there was not much time left for those who wanted to be saved rather than destroyed.

In 1987, Paliau announced that he would die voluntarily and come back as the vessel of the discarnate entity, Wang Jesus, who would then govern the world, in Paliau's body, from the throne of King David (that is, the British Coronation Chair), transported magically from London to Baluan. Makasol members told Schwartz that Paliau had announced that he would be publicly crucified in order to be resurrected, but that he submitted the idea to his followers for a vote and they rejected it. Wanek (1996: 283n11) obtained a colourful account of how in 1987 Paliau staged in the Lorengau market a public counting of the results of what Paliau said had been a secret ballot, leading to immediate cancellation of the scheduled crucifixion. Wanek notes that he could not find anyone who admitted to actually casting one of the ballots, allegedly contained in baskets Paliau brought to the event (cf. Otto 1991: 264). Gustafsson (1995: 77) reports that in 1987 Paliau told her that he had already died, but he had returned to life three days later because his adherents had voted that he should not die. ${ }^{30}$

29 Wanek (1996: 211) reports a more definite version of this prophecy: 'He claimed that Wang Jesus had disclosed that He would come back to the world in the near future, and that members of Makasol had to obey Paliau without questioning his orders, because it was really Wang Jesus who spoke through Paliau. "On the other side of 1990" (as Paliau put it), Wang Jesus would return to the world ... to govern the world by establishing His "Commonwealth of Nations"'.

30 Gustafsson (1995: 77) reports that some of Paliau's followers also claimed to have died and returned to life, after having 'met their ancestors who already lived a life approximating that of Adam and Eve in Paradise'. Such death and resurrection was also, of course, common during the Cemetery Cult of the 1950s. Wanek (1996: 283-4) reports that on Nauna Island, villagers understood that Paliau had predicted that he would die three days before Christmas 1989, three days of darkness would ensue, and Wang Jesus would return, inhabiting Paliau's rejuvenated body. Then 'life would be different for all members of Wind Nation. There would be no more hatwok, no more ageing, no more sickness, no more deaths, and it would be sufficient to tinktink of food and it would materialize ... Every single item [a person] could think of would present itself. Factories would emerge from underground, and every village would get its own factory producing everything from bicycles and corrugated roofing material to money'. 


\section{Paliau as Jesus}

We can't be sure which of Paliau's prophecies were successfully communicated to all the Wind Nation rank and file. Schwartz recalls that most of the people who came to hear Paliau speak during his years in Lorengau were from generations in which few were literate, even in Tok Pisin. Many or most couldn't read even the Tok Pisin version of the 1982 document warning of a worldwide apocalypse, the text of which is reproduced above (cf. Otto 1992a: 59). Paliau's degree-holding Wind Nation leaders intended the English version for public officials and presumably other formally educated people of their own or adjacent generations outside the Movement. In addition to requiring knowledge of English, the document includes a comment on science ('I wish to correct Scientist theory that the five elements are not just mere particles of any sort') that does not appear in the Tok Pisin version. The status of scientific explanation probably was not an issue of much concern to most Movement adherents.

Even so, the overall record suggests that in the prophecies and proclamations of Paliau's last years his emphasis shifted more and more towards his claimed relationship to Jesus. Reports of Paliau's Jesus-like miracles reach back for many years. In addition to being able to control the wind and waves during the days of wonder - as Jesus did on the Sea of Galilee-Paliau is credited by many of his followers with curing the sick, including restoring sight to the blind (cf. Otto 1991: 283). In 2015, some of his followers told Smith that Paliau could walk on water, and claimed to have seen it. Paliau's flirtation with death and resurrection-both as a staged event and as a prophecy-is reminiscent of the Noise, but also the New Testament. At the December 1990 gathering noted above, Paliau called himself the 'maus bilong Yesus' - literally, the mouth of Jesus-and Paliau Lukas spoke (in English) in praise of 'Paliau Maloat who has been following in the footprints of Jesus for the last 45 years, and who I claim now as they are both one in spirit and in flesh that the world must know and learn quickly' (presumably to avoid an apocalypse of non-believers).

During his 2015 visit to Pere, Smith had several conversations with Kumulau Paniu, Wind Nation's amamas lida (that is, worship or celebration leader). In this role Paniu led the daily and weekly gatherings of Pere's Wind Nation adherents. An elderly but robust and energetic man, 
Paniu told Smith that Paliau himself had chosen him as a leader in 1982. ${ }^{31}$ Paniu kept a notebook of things he had heard Paliau say, among them a phrase in Paliau's Baluan language: 'Yesus Hapa? Wong tepo Yesus'. Paniu translated this into Tok Pisin as 'Yesus $i$ we? Mi tasol $i$ Yesus', which translates into English as 'Where is Jesus? I am Jesus [or, perhaps: I alone am Jesus]'. A slightly different translation yields a more ambiguous statement. Ton Otto (personal communication, April 2019) recommends a different spelling of the Baluan phrase (to wit: Jesus a pa? Wong tepwo Jesus) and, more important, a slightly different translation into English: 'Where is Jesus? I now am Jesus/It is me who is Jesus'. This leans more towards suggesting that Paliau is a new vessel for an incorporeal entity, Wang Jesus, rather than being identical with Jesus of Nazareth.

Gustafsson (1995: 76) reports that in March 1989 Paliau 'announced that the last prophet was dead and now he was Jesus. Jesus had gone to Heaven - his body did not remain and therefore no one knew what he would look like when coming back to Earth. According to Paliau, since it was white people who killed him Jesus would come to the black people. This had already happened; he had returned through Paliau, who was Jesus'. Unfortunately, Gustafsson does not say whence her information comes. But Paniu recorded that Paliau declared himself Jesus-in some sense-in 1990. In his notebook, he had also written the question (we translate from Tok Pisin): 'Why does Paliau Maloat say he is Jesus?' And he proposes the following answer: 'Paliau Maloat can say he is Jesus because he wants to strengthen our knowledge and belief and show that he speaks to show the angel that lives inside him how he is a prophet who is Jesus'.

\section{Who did Paliau think he was, anyway?}

In the next chapter we will visit Manus in 2015 and hear a number of opinions on what Paliau accomplished and who he was from people whose lives overlapped with his, and from people who know of Paliau only what they have heard. This is a good time to pause and ask who Paliau thought he was in the last phase of his career. Recall that in 1990, when Schwartz asked Paliau if he had indeed told his followers that he

31 Paniu was never honoured by the British Commonwealth, but he did receive a medal for Meritorious Community Service from the PNG government sometime post-2000. 
was Jesus, Paliau's reply was more nuanced than the statements Kumulau Paniu recorded. Paliau told Schwartz: 'I said to them, who else in the world has such good things to say? It's Jesus! He is a man with good things to say. I said: I'm your Jesus. I'm your Jesus, I told them'. He then said that he had told his followers that he was merely Paliau Maloat, but that he got his teachings from Jesus.

Schwartz never heard Paliau make any stronger claim, either in private or public. Yet we have several reports, like Paniu's, that on some occasions Paliau did indeed do so. Similarly, Paliau Lukas was unequivocal that Paliau Maloat and Jesus were 'one in spirit and in flesh'. He declared this at a public event at which Paliau was present, so Paliau probably would have heard it and he apparently let it pass. As noted in Chapter 11, Paliau often complained to Schwartz that people chronically distorted what he said. But we also know that Paliau was quite capable of letting people attribute to him almost anything they wanted if it helped him to secure his leadership and to get his way. However he saw himself, he was no more likely to contradict Paliau Lukas's announcement that he was 'one in spirit and in flesh' with Jesus than he would have been to blush and protest when someone called him the founder of the Pangu Pati and the father of PNG.

The simplest explanation for Paliau's claiming that he was Jesus and promising universal True Freedom towards the end of his life is that he had become so thoroughly enmeshed in a self-image as leader and innovator that he was willing to go to extremes to maintain it. We nonetheless doubt that Paliau ever regarded himself as a fraud. Schwartz has observed that charismatic leaders often become their own followers-both makers and consumers of their own myths. Otto (1998: 86) elegantly makes much the same point: 'Paliau, in a mutually re-enforcing interaction with his followers, began to live his myth more fully'.

It is also possible that the Paliau of the late 1980s was not the same Paliau who initiated the Movement in the 1940s. In the 1990s, Paliau handled Schwartz's questions about his relationship to Jesus with finesse; but as Paliau approached the end of his life Schwartz found him less introspective in conversation and more rigid and authoritarian in his manner towards his followers. Granted, in the Wind Nation era Paliau was seldom if ever trying to win over political opponents as he did when running for or executing his elected public offices. In the Wind Nation era he was 
generally preaching to the converted. Even so, it is hard to imagine the Paliau who preached the doctrine of Wing, Wang, and Wong even bending enough to leaven his remarks with jokes and comments about the weather as he did in Bunai when he stopped the Cemetery Cult. Rather, Schwartz observed, Paliau in his later years scolded and insulted his listeners with less restraint than ever. ${ }^{32} \mathrm{He}$ had gone from being an imperious leader, who nevertheless knew how to change his tone for tactical reasons, to acting like a fanatic. We cannot rule out the possibility that Paliau suffered a cognitive decline in his last years. When Schwartz last heard Paliau speak in public he saw that he was physically feeble (he needed help walking) and, although Paliau's orations had always been repetitive, he now seemed at times to repeat himself out of confusion rather than for emphasis. ${ }^{33}$

Whatever Paliau's innermost thoughts or his cognitive status during his late career, his leading followers-men like Paliau Lukas, Kisokau Pochapon, Peter Kuwoh, and Martin Poposui Thompson-clearly encouraged him to eschew moderation or subtlety. It is not possible to determine to what extent they may have tried to use Paliau and Wind Nation to bolster their prospects in electoral politics, but—as we argued above-we do not find political opportunism a fully satisfactory explanation for their behaviour. It would be hard to find a mundane electoral motive, for instance, for Paliau Lukas's plea in his letter to Schwartz in 1990 to 'tell the world not to destroy it but to SAFE Manus' by recognising Paliau as the world's saviour. In Chapter 2 we referred to Landes's (2011: 99) dictum that 'the prophet must overcome the innate common sense of most people', and suggested that many of the Manus people who found cargo prophecy even in Paliau's most pragmatically worldly plans were eager for someone to help them put aside the tested ideas about how things work that guided their daily lives. The formally educated men who attached themselves to Paliau may also have been eager for someone to hold out the hope of a more rapid and complete transformation of the world than anyone could achieve via PNG's new bureaucratic institutions, which may well have greatly disappointed them.

32 Wanek (1996: 204-10) describes in similar terms Paliau's address to a Wind Nation gathering in Lorengau in 1986.

33 Even minor mental decline would have made him more subject to the influence of his young enablers, although — as we have already discussed — to what end we can't be certain. 
A much more important question than how Paliau saw himself is why others believed or hoped that Paliau was Jesus or a similar saviour and why some continue to do so. In Lorengau in the late 1980s, Paliau could still draw audiences of from a few dozen to a few hundred people, most of them dressed in the all-white clothing of dedicated supporters (cf. Wanek 1996: 204-5). ${ }^{34}$ And even decades after his death (Paliau died on Baluan in November 1991) many people hold fast to Paliau's legend and teachings. There is no simple answer to the question of why they do so, nor is there an easy explanation of why anyone anywhere takes millenarian claims to heart. We return to these questions in our concluding chapter. But first we take a brief look at the state of Wind Nation today, an institution in which Paliau is known only through a limited written record and people's recollections, not all of which agree.

34 Wanek (1996: 218n5) reports that some Makasol members told him that they did not dare leave the Movement because Paliau would curse them if they did. This never came to our attention, but we have no reason to question it. Nevertheless, we also know that some leading Makasol members did break with Paliau. 
This text is taken from Like Fire: The Paliau Movement and Millenarianism in Melanesia, by Theodore Schwartz and Michael French Smith, published 2021 by ANU Press, The Australian National University, Canberra, Australia.

doi.org/10.22459/LF.2021.13 